\title{
Gaukang and White Coup: Dismantling of Traditional Power
}

\author{
Nila Sastrawati
}

\begin{abstract}
This paper discusses the concept of power adhered to by the South Sulawesi community and explains the power struggle which had occurred both in the past and present. The South Sulawesi community's conceptiontraditional power on power signifies a strong, transcendental relationship between themselves and supernatural powers, wherein all objects possessing certain peculiarities are inseparable from the stable and unchanging cosmic world. Thus, gaukang holds a significant position in the life of the South Sulawesi community, particularly pertaining to matters of power struggle. The waxing and waning of traditional power in South Sulawesi is determined by at least three factors: firstly, a change in power patterns with the emergence of new elites having a commoner background; secondly, incessant resistance to feudalistic rule; and lastly, the application of modern bureaucratic model. The general conclusion of this paper emphasizes the position of gaukang as a central point affecting the various power struggles that occurred throughout the history of the South Sulawesi community. The enactment of Regional Regulation (Perda) No. 5 year 2016 on the Organization of Gowa Regency Local Cultural and Customary Institution provides a peek at how bureaucratic power had dismantled traditional power in Gowa Regency, which included, consequently, the transfer of authority over the royal heirlooms or gaukang of the Gowa Kingdom.
\end{abstract}

Keywords:

gaukang/kalompoang; power; legitimacy.

\section{Introduction}

The waxing and waning of traditional power in South Sulawesi had been occurring for a long period of time as signified by the number of attempts conducted to dismantle it. This article aims to dig deeper by providing explanation on the South Sulawesi community's conception of power and on the efforts of traditional power take over in the Gowa Kingdom through contemporary state regulation by keeping past events as an unabridged narrative up till today.

It is quite widely known that there was, recently, a clash between supporters of the Gowa Regent, Adnan Purichta Ichsan Yasin
Limpo, and the followers of the $37^{\text {th }}$ King of Gowa, Andi Maddusila Andi Idjo, who bears the title I Maddusila Daeng Mannyonri Karaeng Katangka Sultan Aluddin II. The clash between the supporters occurred at the Balla Lompoa Palace and it was triggered by the issuance of the Regional Regulation Draft (Ranperda) on the Organization of Local Customary Institution into what has now become the Regional Regulation (Perda) No. 5 year 2016 on the Organization of Local Cultural and Customary Institution conducted by the Gowa Regency Regional People's Representative Council (DPRD) on August 15, 2016. This

\footnotetext{
- Departement of Criminal and Constitutional Law, Alauddin State Islamic University, Makassar.

Email: sastrawatinila@gmail.com
} 
Perda became controversial since one of its articles establishes the Regent as Head of the Customary Institution functioning as Sombayya ri Gowa (King).

The establishment of Regent as Sombayya implies authority over all assets of the Gowa Kingdom, including gaukang or the royal heirlooms. Gaukang is at times known as kalompoang or arajang, wherein the latter means grand. Gaukang in the South Sulawesi community's conception of power serves as the epicenter of cosmic power retained by the karaeng (monarchs) (Hudjolly and Marjaka, 2010). It is through the ownership of gaukang that the karaeng may be revered as ajjoareng (patron) or one who is a role model with loyal followers commonly called joa (client). It may be stated that the Regent's authority over Gowa Kingdom's entire asset in his function as Sombayya may attract more joa into his circle.

The various literatures explaining the traditional political system in South Sulawesi place gaukang as a symbolization of power that influences the South Sulawesi community's perception. Heddy Shri Ahimsa-Putra (2007) in his writing entitled Patron dan Klien di Sulawesi Selatan (Patron and Client in South Sulawesi) elaborates that gaukang or kalompoang is no mere royal heirloom because one's authority over Gaukang or Kalompoang subsequently determines one's social layer within the South Sulawesi community and it further leads to the creation of a strong patron-client relationship. Individuals retaining ownership or authority of Gaukang will consequently become a patron (ajjoareng) while those who does not own gaukang will be the client (joa). In addition to Ahimsa-Putra (2007), Pelras (2006), Poelinggomang (2004), Hudjolly and Marjaka (2010) also provide elaborations on the significance of gaukang ownership/authority to the South Sulawesi community. Moreover, Arsal et al. (2014) gave an explanation on the pattern of power inheritance in the South Sulawesi community.
The position of gaukang, as a basis of one's legitimacy as kekaraengan, was influential in various power struggles which occurred in South Sulawesi. In the past, an individual must seize the gaukang, as the most significant item, in order to take power from or conquer the area of a karaeng. The transfer of gaukang ownership from its previous owner signifies the fall of a karaeng's power. However, in the current period, power struggle is not only a matter of struggle for gaukang ownership, but also entails the dismantling of power through means of modern bureaucratic legal authority. This use of legal means to take away power is what I define to be a white coup (d'état), i.e. an effort in taking over traditional power by making use of regional/state legislation. Hence, the advent of Perda No. 5/2016 on Local Customary Institution became an entry point in elaborating the incidence of white coup after the New Order era. The white coup phenomenon is an interesting issue to raise amid the intensive efforts of traditional rulers to enliven the monarchy's traditional customs, and they are quite often involved in the contestation of local politics in Indonesia.

A frame is established for this article by posing the following questions: how is gaukang conceptualized by the South Sulawesi community; what is the process of white coup in the Gowa Kingdom; and, how did the decline of traditional power happen in South Sulawesi. The answers to these questions will be provided by utilizing the concept of power in the tradition of the South Sulawesi community.

\section{Methods}

This working paper uses qualitative research with case study design. This research is intended to assist deeply understanding and interpreting any behind occurring/existing events. Creswell defines qualitative approach as a process of understanding human or social matters, based on a complex structure, holistic description, formed by words, reported in 
details and undergone in a natural/genuine context (Creswell, 1994: 2). This case study design is chosen because of this research is related to a specific phase or has its own characteristic associated with contemporary phenomenon.

This research was conducted in 2016 which started by collected news in both print and electronic media related to the pros and cons of determining the Perda $L A D$ in Gowa Regency. In addition to collecting news, the author also collected some research results, especially anthropological notes to understand the issues under study. This step was done in order to understand how the people of South Sulawesi in the past interpret the power of comparison and then used as a started point to understand the events that occurred in Gowa regency today. Because this case was very sensitive, this study does not allow in-depth interviews to both parties in conflict. Therefore, this study was based solely on the available literature.

Data analysis was done by means of data reduction by reviewing through the selection, focusing and simplification and abstracting the rough data already possessed. Subsequently, the data has been reduced, analyzed with reference to the theoretical flow, then classified or categorized according to the sequence of discussion and adapted to the purpose of the studied. The final stage is the conclusion. From the data that has been analyzed then the next researcher will draw conclusions related to field findings or research results were undertaken.

\section{Results and Discussion}

\section{Gaukang and the South Sulawesi Community's Conception of Power}

Ahimsa-Putra (2007) distinguishes two types of karaeng in South Sulawesi. The first type refers to karaeng who are descendants of To Manurung, the founding fathers of the prevailing monarchies. To Manurung is considered as a figure who descended from heaven to earth with the purpose of creating peace and order in the region where he initially appeared. Due to the people's belief of his heavenly origin, the figure of To Manurung is then personified as an individual who retains specialness and is, thus, exalted to be the leader in accordance to the agreement between the anang (group) residing in a wanua (region) with the To Manurung. The consensus that resulted in a mutual term of understanding is a form of the anang's self submission to acquiesce to and obey the decisions and order of the To Manurung (Hudjolly, \& Marjaka, 2010: 144). The ascension of To Manurung in modern politics is known as a social contract.

As for the second type of karaeng, it refers to the karaeng's ownership over elements of the environment. This second type of karaeng may be explained by referring to Adams' statement (in Ahimsa-Putra, 2007: 106) concerning power. Adams said that:

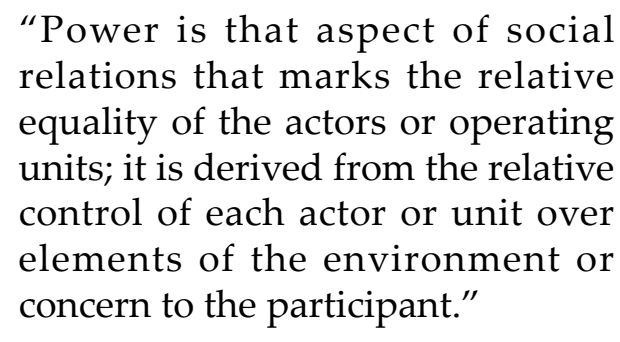

The sources of power pertaining to the division of these two karaeng can at least be traced accordingly, wherein the former is obtained from rights of origin and the latter is control or ownership of elements of the environment which becomes the basis for the social power a karaeng yields.

The people of South Sulawesi believes that the karaeng are owners of heirlooms known as gaukang or kalompoang. At a certain level, the elders in South Sulawesi consider that the actual karaeng is the gaukang or kalompoang itself because the owner of the land, plantation, agricultural field, fish pond, and forest is the gaukang. The karaeng is then regarded only as a guardian or keeper of the gaukang (AhimsaPutra, 2007: 108). 
To the South Sulawesi community, gaukang or kalompoang is no mere ornament as it is the gaukang that governs and arranges all matter are having power over them, it is even regarded as the determiner of life. The gaukang itself are objects that the community consider to have distinct characteristics and peculiar shapes. The particularity of shapes and characters the gaukang have is an indication of purity, and of its supernatural powers, which is the reason why these objects are considered to be the protector of the community and the center of power (Hudjolly, \& Marjaka, 2010: 150).

The way the people of South Sulawesi conceptualize power signifies the presence of a strong or transcendental relationship between themselves and supernatural powers, in which all objects bearing particular characteristics are constantly bounded by the stable and unchanging world of cosmos. The belief in these objects, may be understood genealogically by tracing it back to the position of the To Manurung that is revered as a figure descending from heaven. This means that the presence of all things "peculiar" correlates to powers existing externally beyond themselves.

Such belief is not far too different with the Javanese concept of power which observes that "power is not a theoretical postulate but an existential reality" (Anderson, 1990: 47), meaning that power is real and it is sustained by a never changing power of the supernatural. It is mysterious, intangible, and transcendental. Power may take the forms of natural objects such as rocks, fire, stones and such. This view is, surely, in line to Adams' conception that places control over elements of the environment as the basis in the advent of power. Hence, gaukang ownership becomes a capital to induce influence, submission, and obedience in the community.

Gunawan and Isbodroini (2005: 209) elaborate that although the king serves as the center of mystical and cosmic power in the Javanese conception, the king's reign still requires support from symbolic sources as a basis of legitimacy, such as royal heirlooms. Meanwhile, in the Western tradition (Murphy, 2011; Afandi, 2012;), power is understood as a particular situation occurring within human social relations, and it is concurrently understood that the use of power in those relations to induce influence must at least fulfill the bare requirement, namely the fulfillment of resources enabling one to influence another. Andrain (1992) mentions at least five types of resources that may be utilized by an individual to gain influence. First, physical resource. This is a resource type that relies on employing instruments/tools capable of causing bodily harm upon others, such as weapons. This demonstrates that the use of physical power for threat is necessary to implant obedience in the self of another. Second, economic resource. This resource type emphasizes wealth as an instrument to subdue and enforce obedience in the masses. Third, personal resource. Such resource type places the personal qualities individuals possess to have the capacity of instilling obedience in others. Fourth, expert resource. This refers to individuals bearing certain expertise not found in others that may easily create obedience. This is due to the fact that experts have certain particular knowledge and information unavailable to others. Fifth, normative resource. This resource type assumes that people possessing normative power will subsequently possess self-qualities relating to wisdom, moral righteousness, and rights of authority. Thus, the possession of normative resource affords them the moral rights to administer power (Andrain, 1992: 134).

This type of normative resource is not different to the explanations provided by Adams and Anderson (1990) that the most significant matter in the exercise of power is the acknowledgement that an individual possesses the moral rights to administer power according to the traditions and beliefs found 
in a particular community. A community that consecrates objects deemed to be the embodiment of cosmic or supernatural beings will consequently submit to individuals controlling such objects. It does not matter how one obtains the object, as the significance is on the belief that it may bring hazard and peril.

The South Sulawesi community believes that gaukang serves as the center of all power an individual possesses. Thus, anyone in possession of a gaukang will instantaneously instill obedience in the community. Referring to the elaboration provided by Adams, the source of one's social power depends on how strong and substantial one's control is over elements of the environment. That in order to establish power, one should collect and accumulate all heirlooms regarded to bear mystical power as symbols of power.

Although gaukang is regarded as the center of power, it still requires a medium capable of fulfilling the desires of the gaukang upon the people. Hence, it is the owner who implements the will of the gaukang and serves as the leader in the community (Ahimsa-Putra, 2007: 110). In addition to having intent or desire, gaukang also has needs. This results in the gaukang being treated properly with respect, and a special place is prepared in the house. It is usually kept in the front room of the house together with its guardian. These guardians are subsequently called karaeng. One of the traditions that remain to be continued in the Gowa Kingdom today is the accera kalompoang, wherein the heirlooms owned by the Gowa Kingdom are cleansed, and this commonly takes place after the Eid al-Adha.

The South Sulawesi community's concept of power that is centered on the gaukang or kalompoang may provide insights on various political events and power struggles which had occurred throughout the monarchies in South Sulawesi, since power struggles are always connected to the gaukang or kalompoang. The current incident in the Balla Lompoa Palace and the advent of Regional Regulation No. $5 / 2016$, may be explained by referring to how gaukang were fought for in the context of power struggles.

\section{Gaukang and Power Struggle in South Sulawesi}

The history of power struggle in South Sulawesi is observed to have mainly involved the appropriation of gaukang. Once an enemy seized possession of a gaukang, the initial owner of the gaukang is consequently deemed defeated. Several incidents demonstrate the position of gaukang in power struggles that had occurred in South Sulawesi. Ahimsa-Putra (2007) summarizes a number of power struggle incidents by elaborating the findings recorded by researchers in the colonial period, in which one of them is the records made by Kooreman and Goedhart.

Kooreman recorded that in 1879 there was an incident in Polombangkeng which involved Gallarang Mangasa who attempted to gain control of all heirlooms the Kingdom of Gowa had, although he actually failed to do so. There was also a record on the murder of the Bulo-Bulo regent in 1872, wherein the murderer succeeded in obtaining the gaukang the regent had in his possession which was subsequently used to facilitate in the fight against the Dutch.

Goedhart provided records of incidents which happened around the early $16^{\text {th }}$ century. The Gowa Kingdom, at the time, intended to expand its rule, yet it was unable to defeat the Karaeng Lowe from Bajing. Coincidentally, the child of Karaeng Lowe was married to Karaeng Galesong who then schemed his tactics in getting Bajing to surrender. By using various means, Karaeng Galesong eventually gained control of the gaukang owned by Karaeng Lowe from Bajing, and with the acquisition of the gaukang, Karaeng Lowe was symbolically declared defeated and must submit to the rule of the Gowa Kingdom. Karaeng Galesong was then afforded rewards in the form of kampong 
and forest area for succeeding in defeating Bajing.

In 1880, the regent of Bantaeng was instructed to capture Karaeng Rumbia but failed. One of the tactics used to dismantle Karaeng Rumbia's power is by removing Hadat Rumbia, and the title of karaeng was then replaced with gallarang. However, the Rumbia community still acknowledged Karaeng Rumbia as the true karaeng because the gaukang that binded the four regions forming the kekaraengan remained in his control.

In addition to Kooreman and Goedhart, Poelingomang also stated that the reason for I Sangkilang to proclaim himself as the Batara of the Gowa Kingdom was because he presented a gaukang or kalompoang of the Gowa Kingdom that he had in his possession in the form of sudanga. Through his control over the said gaukang, he was able to produce obedience and gain numerous followers who were commoners and some who were palace aristocrats. As I Sangkilan succeeded in garnering numerous followers, he then attempted to seize Gowa's power (Poelinggomang, 2004: 57).

The incidents above provide an illustration on the position of gaukang in the South Sulawesi community's conception of power, wherein the power a karaeng wields is determined by their gaukang ownership. Gaukang as the true karaeng provides legitimacy for all exercise of power conducted by its guardian. Hence, Adams' statement that power can only be acquired by using elements of the environment believed by the residing community is not an exaggeration.

In addition to being a part of narratives pertaining to power struggles, stories of gaukang in the daily lives of the South Sulawesi community can also be observed. There was an incident which occurred in 1864-1865, it was a time when the cholera plague was rampant and had resulted in thousands of victims. An ornament party for heirlooms was thus held based on the community's belief concerning the gaukang or kalompoang. Once the party was conducted, the cholera plague had gradually disappeared. In 1874-1875, the disease raged again, and Karaeng Gantarang along with the regional chiefs under his authority requested the Dutch controller to conduct a similar party. The various heirlooms, such as spear, shield, water basin, betel plate, umbrella and others, were paraded through the streets led directly by the regent (Ahimsa-Putra, 2007: 110-111).

The variety of phenomenon above show the centrality of gaukang in the life of the South Sulawesi community. Gaukang is not merely regarded as a common ornament with no correlation to the cosmic world, it is an actualization of power from another world, and it has its own will and necessities. Gaukang may generate calamities if the community does not abide to its will, and conversely, the community will become prosperous and peaceful if they show obedience and submit to all the gaukang's will represented by its guardian.

\section{White Coup: Dismantling Traditional Power?}

As previously explained, there were power struggles ending in bloodshed that had occurred in South Sulawesi and even in other regions throughout history. It is observed that past power struggles were carried out through war and killing by using gaukang to seek legitimacy of power after the war, hence, this article uses the term white coup to illustrate the process of dismantling traditional power which took place from the 1950s to the 1960s. White coup is defined as the taking over of traditional power by utilizing the power of the modern state to acquisition traditional power authority through state regulations.

The advent of the Regional Regulation No. 5/2016 on the Organization of Local Cultural and Customary Institution (Perda LAD) in the Gowa Regency may be stated as repeating history wherein the state had destroyed the traditional rulers and forced them to submit to the power of the modern state. Although the level and patterns employed are different, the 
cleansing of prevailing aristocratic remnants becomes unavoidable to this day. The case of the Yogyakarta Sultanate is a different matter as they were able to obtain acknowledgement from the state through the passing of the law on Yogyakarta's special status.

The return of sultans on the political stages of various regions may be considered a threat to local strongmen in the post reform period. Their emergence is consequently to become competitors in the fight for influence in the community. Since the fall of the New Order, the aristocrats in South Sulawesi also began taking part in political contestation, including the successor of the King of Gowa, Andi Maddusila Andi Idjo.

The rivalry between Andi Maddusila Andi Idjo and the family of Yasin Limpo has been ongoing for quite some time since the initiation of the direct election for regional head, with Andi Maddusila always being the loosing party. It started with the father of the current regent, Ichsan Yasin Limpo, who had held office for two periods, up to the recent regional election that pitted Andi Maddusila with Adnan P. Ichsan Yasin Limpo, and still resulted in the loss of the Gowa King's successor.

The rivalry between the two families did not actually end at the regional election as the enactment of the Regional Regulation No. $5 / 2016$ on the Organization of Local Cultural and Customary Institution had led to new conflict. One of the contents of the Regional Regulation is the appointment of the regent as the head of the local customary institution (Lembaga Adat Daerah - LAD) with the capacity to perform the function of Sombayya (rakyatku. com, 08/09/2016). It has been clarified that there are no stipulations in the verses of the regional regulation mentioning that the regent is the king or Sombayya, except that in the general provisions there is a specification on performing the function of Sombayya (makassar.tribunnews.com, 16/09//2016). This may subsequently be defined that the regent has the capacity to carry out the functions of Sombayya or the king, and this is the crux of the controversy as of current.

Republika in its report explains "based on the stipulations of the Gowa Regency regional regulation on LAD which was subsequently changed into the Regional Regulation on the Organization of Local Cultural and Customary Institution, in some of the articles wherein one of them was revised, that is Chapter III Article 3 stipulating that the Regent of Gowa is the Head of the Local Customary Institution with the role of carrying out the functions as a Somba or leader. Meanwhile, based on the rules of the monarch, the appointment of a Somba is not so simple and the candidate must be of aristocratic descent. The candidate's royal heritage, kingdom of origin, and bloodline must be clear to understand his ancestral lineage. Whereas, in the regional regulation, prior to its amendment, it was stipulated that the Regent of Gowa is king, and it was hastily revised as not to offend descendants of the true king. There is, consequently, no provision in the current Regional Regulation stating that the Regent of Gowa is the King of Gowa, the regent functions as Sombayya ri Gowa instead." (Aminah, 2016).

The inauguration of the regent as head of the customary institution, on September 8, 2016, led to various reactions from numerous parties, particularly Andi Maddusila. Andi Maddusila who was inaugurated as the $37^{\text {th }}$ king of Gowa by Batesalapang said that

"based on the consultation result
with the Ministry of Internal Affairs,
the regional regulation is considered
to violate the Constitution that
organizes sultanates and kingdoms.
Hence, from a legal perspective it is
illegitimate." (Aminah, 2016)

There were also some criticism regarding the attempt of a forceful opening of a safe 
in which a kalompoang or gaukang of Gowa, the Salokoa (crown), was stored in the Balla Lompoa Palace. The royal safe was forcefully opened and a report on the forceful opening of the safe was made on September 7, 2016. The regional administration declared in their defense that there was information stating the royal crown, which is a royal heritage and ornament, had become missing. For that reason, the regional government forcefully opened the safe, although it is known that the key holder is Andi Maknum Bau Tayang who is a relative of Andi Maddusila, yet the safe was still opened forcefully (Aminah, 2016).

The implications in the implementation of this regional regulation will bring about more significant consequences. The regent as the modern state's bureaucratic instrument who is also the head of the LAD conducting the functions of Sombayya may easily control all sorts of gaukang or kalompoang owned by the Gowa Kingdom. Additionally, all of the regent's conducts may be manipulated to be in the interest of Sombayya because his position in the hierarchy of traditional power is given legitimacy through state/regional legislations. This means that, referring to the layer of traditional power in South Sulawesi community, the regent may demand cultural obedience as a symbol of submission to the monarch.

Although the reasoning given for the issuance of the LAD regulation is to maintain and preserve traditions and heritage of the Gowa Kingdom, a general question of why should the regent carry out functions as Sombayya instead of the direct descendants of the Gowa royal family, is justified. Keeping in mind that Andi Maddusila is the direct descendant of the $36^{\text {th }}$ King of Gowa and has been inaugurated by the Batesalapang as the $37^{\text {th }}$ King of Gowa, it is considerably reasonable for some to consider the advent of the LAD regulation and the initiation of the regent as head of LAD to be an attempt to seize power from the Kingdom of Gowa.
The history of power struggle in South Sulawesi had occurred through various means and motives. Hudjolly and Marjaka (2010: 149), referring to the traditional Bugis concept of power, state that the successive ruler is not always based on heredity as a guarantee for obtaining a position of power, as there is no definite ruling to be referred to in the kingdom's succession process. Nevertheless, it is commonly considered that the selected candidate should be one of the descendants out of the numerous other lineages of past rulers, and the candidate may only be from a particular status. Hence, the next specification in determining the successive ruler is for the candidate who has the most substantial amount of joa (followers), and is supported by the most influential followers. This means that the strength of a person's legitimacy to hold a position of power is determined by the number of followers or joa one amasses.

There was also a power struggle in the Gowa Kingdom on April 1739 invoked by Karaeng Bontolangkasa in collaboration with Arung Matowa Wajo. At the time, I Mallawagau Sultan Abdul Khair Al-Mansyur who was still 12 years old and inaugurated as the successor to his grandfather Sultan Sirajuddin the $23^{\text {rd }}$ King at the age of 8, left the Gowa Kingdom and gained entry to the Ujung Pandang Fort to request assistance from the Dutch. Meanwhile, the force headed by Karaeng Bontolangkasa had surrounded the fort of Ujung Pandang and had occupied the capital of the Gowa Kingdom, and concurrently had also dethroned Sultan Abdul Khair Al-Mansyur from the reign of the Gowa Kingdom, and he appointed himself as the king of Gowa. On the other hand, Karaeng Bontomajannang felt entitled to be the king of Gowa because he felt he had contributed greatly to the greatness of the Gowa Kingdom (Yasen, 2008: 10).

Past succession of power may be regarded as having been achieved through war and bloodshed, while the current LAD regulation 
may be considered similarly as an attempt to dismantle traditional power through the use of state/regional legislation. The current white coup is not the first of its kind experienced by the Kingdom of Gowa. The conversion of the Gowa Kingdom's government into a Level II Region based on Law No. 2/1957 on the Formation of Level II Regions of Makassar, Gowa, Takalar, and Janeponto that was strengthened by Law No. 29/1959 on the Formation of Level II Regions in Sulawesi (State Gazette Year 1959, Addendum to the State Gazette of the Republic of Indonesia Number 1822) is regarded as the first white coup. Meanwhile, the initiation of the $36^{\text {th }}$ King of Gowa, Andi Idjo Daeng Mattawang Karaeng Lalolang Sultan Aiduddin Tuminanga Ri Jongaya, as the first regent of Gowa Regency marked the end of the Gowa Kingdom's governing of its regions and the beginning of the modern bureaucratic system.

\section{Aftermath of the White Coup: Gaukang and State Legislation}

The currently occurring white coup is a narrative that is inseparable from past incidents of power struggle. The white coup of the contemporary era has been added to the long list of existing patterns of power struggles that ultimately exacerbates the degradation of traditional power in South Sulawesi.

After the white coup, what remains to be questioned is whether the South Sulawesi community, particularly the people of Gowa, acknowledges the validity of the power take over or do they instead condemn this act. It should be kept in mind, as mentioned by Hudjolly and Marjaka (2010: 143), that "winning and losing in wars only relate to physical power, but acknowledgement of power/authority after victory of war without gaukang or sacred heritage would only produce repressive authority by taking advantage in the psychological nature of the loosing party's fear and obligation. Gaukang and the sacred heritage objects is a strategy mechanism in the cycle of power itself". It may be understood from the given explanation that the most significant matter is the people's acknowledgement following the coup of power that is proven by the control of gaukang.

Despite the white coup having been carried out in the Kingdom of Gowa, the Regent's legitimacy as the Sombayya will remain to be questioned since the gaukang or kalompoang Salokoa is not in his possession. Hence, the attempt at forcefully opening the safe of the Salokoa by the regional government at the Balla Lompoa Palace prior to the initiation of the Regent as the head of LAD or Sombayya, is considered as a reasonable motive. The Salokoa must be presented in the initiation as Sombayya in order to obtain cultural legitimacy, as the lack of it would render the ceremony meaningless.

Although the Regent has been inaugurated as the head of LAD conducting the functions of Sombayya, in reality, it is very difficult to acquire legitimacy from the people of Gowa. This is proven with the appearance of various forms of rejection carried out by the wider community in South Sulawesi. Adi Suryadi Culla, one of the lecturers at Hasanuddin University made a petition letter on www.change.org which has been signed by thousands of people as a form of rejection to the Regent's appointment as Sombayya because it is regarded to have impaired the customary system and cultural values of Gowa (Kompas. com, September 13, 2016).

Meanwhile, a day before, Kompas. com also reported a clash that happened at the Ballo Lompoa Palace between the kingdom's guardsmen who rejected the Regent's appointment as Sombayya and the Civil Service Police Unit (Satpol PP) assisted by local thugs (Kompas.com, September 12, 2016). The clash had occurred on the same day as the conduction of the accera kalompoang ritual and it was triggered by the kingdom guardsmen intending to enter Ballo Lompoa Palace being prevented by Satpol PP. 
On the $26^{\text {th }}$ of September, 2016, a huge protest took place at the Gowa Regency Regional People's Representative Council (DPRD) office to push the council members to revoke the LAD regional regulation which appoints the regent as Sombayya. The protest ended in the burning of the DPRD office and several damages (makassar.tribunnews.com, September 26, 2016).

The support for Andi Maddusila (the $37^{\text {th }}$ King) not only came from the people of Gowa, as numerous supports were also observed to flow in from several kings of monarchies in Indonesia who accompanied Andi Maddusila in visiting the Indonesian Police Headquarters to report the unrest occurring in the Gowa Kingdom (Alvionitasari: 2016).

These various forms of rejection may be understood with the explanation that becoming Sombayya in the perspective of the South Sulawesi community is inseparable from the ownership of gaukang or kalompoang. Sombayya is considered as the person carrying out the will of the gaukang that directly relates to the supernatural world. Thus, a Sombayya or karaeng in possession of gaukang should have the capability of translating the will of the gaukang.

Despite the Regent's rightful legitimacy afforded by the state, the people of Gowa remains loyal in declaring Andi Maddusila as the ruler of the Gowa Kingdom. Therefore, when referring to the South Sulawesi community's conception of power, Andi Maddusila is the only individual capable of controlling the royal gaukang or kalompoang and carrying out the will of the gaukang. It can subsequently be explained, as mentioned by Hudjolly and Marjaka (2010: 143), that after the war or power struggle, the ultimate determining factor is who controls the gaukang or kalompoang, not who won the war. Although the Regent has been inaugurated as Sombayya, at the end of the day, the obedience of the joa (followers) depends on who is in possession of the gaukang.

\section{The Current Degradation of Traditional Power}

Although Andi Maddusila is acknowledged as the king to throne of the Gowa Kingdom and the legitimate heir of the Gowa Kingdom's gaukang or kalompoang, the appeal and influence of the institution known as the Kingdom of Gowa in governing and controlling the people may be said to have diminished. Generally, the people of Gowa obey state regulations, yet they still admit that the traditions of the Gowa Kingdom need to be preserved. Hence, the rituals carried out by the Gowa Kingdom at the Balla Lompoa Palace is necessary to preserve the traditional customs of the monarchy.

The current degradation of traditional power in governing and controlling the people is actually the culmination of a series of various past incidents. This degradation can generally be seen from changes in the power pattern, wherein new elites began to surface from the maradeka (free people) and commoners. The emergence of new elites from the maradeka people consequently created new patterns of patronage. People no longer rely on the karaeng as ajjoareng. Whereas, in the past, the maradeka people were the joa. People who felt they serve as the joa would voluntarily follow the will of the ajjoareng and they would always show their loyalty to the ajjoareng in any type of situation any where (Ahimsa-Putra, 2007: 13).

Additionally, the degradation of traditional power is also caused by the intensity of resistance to feudalistic authority. According to Pelras (2006: 338) the rule of the royals had almost actually reached its lowest point due to recurring rebellions defying their reign and being considered as a feudalistic ruler with the belief of infidels. At the time, there were numerous symbols of majesty (gaukang, kalompoang, arajang) that were destroyed. Besides being based on belief, the 1945 national revolution, in reality, was also intended to fight against the aristocracy as a part of the battle 
against feudalistic power which had often ended with bloodshed (Klinken, 2010: 167).

Lastly, the cause of its degradation is the implementation of the modern bureaucracy. The application of modern bureaucratic system in the monarchies of South Sulawesi can be traced back to the Dutch's success in governing the entire region of South Sulawesi. The Dutch introduced a new administrative system that compartmentalized various particular regions into rigid restrictions. The territorial division based on the "self-governing region" system that was applied in South Sulawesi was adopted from a system employed in the island of Java. This system distributes regions into residencies (afdelingen - karesidenan) and regencies (onderafdelingen - kabupaten), wherein consecutively Dutch district officers known as residents and controllers were appointed as advisors to the local rulers (Pelras, 2006: 328).

Further explanation is provided by Hasan (2012: 1078) that during the reign of the Dutch colonial government, a dualism of bureaucratic system was occurring. Despite the fact that the Dutch colonial government had introduced modern administrative and bureaucratic systems, the traditional administrative system that had been implemented for ages by monarchies throughout the archipelago was, in reality, continued to be maintained.

The rationalization of government system conducted by dividing the regional authority of monarchies in Dutch East Indies is inseparable from the enactment of the decentralization law. Although in 1903 the elites of Europe in Dutch East Indies were given restricted self government capacity, according to Benda (in Nordholt \& Klinken, 2007: 13), the new law did not have any provisions relating to issues of autonomy. It was since the enactment of the 1922 decentralization law that the newly formed provinces had gained a considerably more significant administrative autonomy.

Long before the implementation of the decentralization law which led to a revitalization of the bureaucratic administrative system, the degradation of traditional power had long been endured by the Kingdom of Gowa. This is observed to have occurred since the implementation of the 1667 Bungaya Agreement which was unfavorable to the Gowa Kingdom. The agreement created factions among the aristocracy, that is those who agreed and those who opposed the agreement. Those who did not agree to the signing of the agreement were Karaeng Bontomarannu, Karaeng Karunrung, Karaeng Tallo, Karaeng Popo and Karaeng Langkese, several prominent figures even chose to leave the kingdom (Rochayati, 2010: 87).

The role of the Gowa Kingdom in governing the lives of its people had ended since the transference of the Gowa Kingdom administration into a Level II Region based on Law No. 2/1957 on the Formation of Level II Regions of Makassar, Gowa, Takalar and Jeneponto. This was further strengthened by Law No. 29/1959 on the Formation of Level II Regions in Sulawesi (State Gazette Year 1959, Addendum to the State Gazette of the Republic of Indonesia Number 1822).

Meanwhile, the $36^{\text {th }}$ King of Gowa, Andi Idjo Daeng Mattawang Karaeng Lalolang Sultan Aiduddin Tuminanga Ri Jongaya, was appointed as the first Regent of the Gowa Regency. This appointment marked the end of the Gowa Kingdom in governing its territory and the beginning of the modern bureaucratic system.

Megenda provides a general summary, as quoted by Klinken (2010:1967), that from the 1950s to the 1960s, the monarchies of Indonesia that initially succeeded in surviving the Dutch occupation period, were eventually brought down. This was signified with the advent of various legislations from the newly established Indonesian state that dismantled the influence of monarchial powers both in politics and economy.

The series of the above incidents became the starting point in the current degradation of traditional power. Gaukang is no longer the 
only reason for an individual to become joa and ajjoareng, thereby causing the gradually diminishing power of gaukang ownership. In addition to the current white coup, the prevailing traditional power in the Kingdom of Gowa is progressively sinking into its lowest point.

\section{Conclusion}

Based on the above elaborations, it can be concluded that the traditional community of South Sulawesi generally perceive power to be founded on symbolization of the cosmic world. Power is understood as an individual's moral right to govern based on the many superiorities one has originating from powers of the supernatural world. These powers are considered to be embodied in numerous objects, the gaukang is, thus, regarded as the embodiment of cosmic world power. People who are in possession of gaukang and are the medium for implementing the will of the gaukang must be obeyed. The way the traditional community of South Sulawesi conceptualize power signifies a strong or transcendental relation between themselves and supernatural power, wherein all objects bearing particular characteristics are inseparable from the stable and unchanging world of cosmos. Obedience to the gaukang is a symbolization of submission to the cosmic world that governs the life of man.

Therefore, gaukang ownership becomes the basis for one's legitimacy to power. Although the white coup, that is the attempt in utilizing state power to dismantle traditional power, had occurred in the Kingdom of Gowa, in reality, acknowledgement to the takeover of power by appointing the Regent as Sombayya was ineffective in gaining cultural legitimacy because the gaukang or kalompoang called Salokoa has not been appropriated. Historically, power struggles in South Sulawesi are inseparable from the role of gaukang. Victory in the contestation for power can only be acknowledged when the gaukang has been seized.
The current white coup observed in the Gowa Kingdom is one of a series of past incidents that adds to the long list of causes exacerbating the degradation of South Sulawesi's traditional power. Generally, the degradation of traditional power in South Sulawesi is caused by, firstly, change in power patterns with the advent of new elites having a commoner background; secondly, incessant resistance to feudalistic rule; and lastly, the implementation of modern bureaucratic model.

\section{References}

Afandi, A. K. (2012). Konsep Kekuasan Michel Foucault. Teosofi: Jurnal Tasawuf dan Pemikiran Islam, 2(1), 131-149.

Ahimsa-Putra, H.S. (2007). Patron dan Klien di Sulawesi Selatan: Sebuah Kajian FungsionalStruktural. Yogyakarta: Kepel Press.

Alvionitasari, R. (2016, September 30). Raja Gowa Mengadu ke Mabes Polri. Tempo. Retrieved July 12, 2017, form https://m. tempo.co/read/news/2016/09/30/078808658/ raja-gowa-mengadu-ke-mabes-polri.

Aminah, A. N. (2016, September 12). Raja Gowa: Perda Lembaga Adat tidak Sah. Republika. Retrieved from http://www.republika.co.id/ berita/nasional/daerah/16/09/12/ode0jf384raja-gowa-perda-lembaga-adat-tidak-sah. Anderson, B.R. O'G. (1990). Kuasa-Kata: Jelajah Budaya-Budaya Politik di Indonesia. Yogyakarta: Mata Bangsa.

Andrain, C. F. (1992). Kehidupan Politik dan Perubahan Sosial. Yogyakarta: Tiara Wacana. Arfah, H. (2016, September 16). Pakar Hukum: Bupati Gowa Harus Jalankan Perda LAD. Tribunnews. Retrieved September 23, 2016, from http://makassar.tribunnews. com/2016/09/16/pakar-hukum-bupatigowa-harus-jalankan-perda-lad.

Arsal, T., Wahyuni, E. S., Pandjaitan, N. K., \& Hubeis, A. V. S. (2014). Politik Perkawinan dan Pola Pewarisan Kekuasaan di Konfederasi Ajatappareng, Sulawesi Selatan. Paramita, 24(1), 78-91. 
Cipto, H. (2016, September 13). Beredar Surat Petisi Penolakan Bupati Menjadi Raja Gowa. Kompas. Retrieved July 12, 2017, from http://regional.kompas.com/ $\mathrm{read} / 2016 / 09 / 13 / 13484781 /$ beredar.surat. petisi.penolakan.bupati.menjadi.raja.gowa.

Creswell, J. W. (1994). Research Design Qualitantive \& Quantitative Approaches. London: Sage.

Fadli, A. C. (2016, September 8). Bupati Gowa Dikukuhkan Sebagai Ketua Lembaga Adat Daerah. Rakyatku News. Retrieved from September 23, 2016, from http://news. rakyatku.com/read/19966/2016/09/08/ bupati-gowa-dikukuhkan-sebagai-ketualembaga-adat-daerah.

Gunawan, S., \& Isbodroini. (2005). Faham Kekuasaan Jawa: Pandangan Elit Kraton Surakarta dan Yogyakarta. Antropologi Indonesia, 29(2), 207-218.

Haq, A. (2016, September 12). Kisruh Kerajaan Gowa, Pasukan Kerajaan Kembali Bentrok dengan Satpol PP. Kompas. Retrieved July, 12, 2017, from http://nasional.kompas.com/ $\mathrm{read} / 2016 / 09 / 12 / 20244981 /$ kisruh.kerajaan. gowa.pasukan.kerajaan.kembali.bentrok. dengan.satpol.pp.

Hasan, M. N. (2012). Corak Budaya Birokrasi pada Masa Kerajaan, Kolonial Belanda hingga di Era Desentralisasi dalam Pelayanan Publik. Jurnal Hukum, 28(2), 1073-1087.

Hudjolly, \& Marjaka. (2010). Gaukang dan Keraton: Strategi Kekuasaan. In Hudjolly, etc (Eds.) Nalar dan Tradisi. Yogyakarta: Re-Kreasi.

Klinken, v. G. (2010). Kembalinya Para Sultan: Pentas Gerakan Komunitarian dalam Politik Lokal. In J.S. Davidson \& D. Henley, S. Moniaga (Eds.), Adat dalam Politik Indonesia. Jakarta: Yayasan Obor Indonesia \& KITLVJakarta.

Murphy, J. B. (2011). Perspectives on Power. Journal of Political Power, 4(1), 87-103.

Nordholt, H. S. \& Klinken, v. G. (2007). Introduction. In H. S. Nordholt \& G. v. Klinken (Eds.), Politik Lokal di Indonesia (pp. 12). Jakarta: Yayasan Obor Indonesia \& KITLV-Jakarta.

Nurmin, W. O. (2016, September 26). Breaking News: Demo Soal Kerajaan Gowa, Kantor DPRD Kebakaran. Tribunnews. Retrieved July 12, 2017, from http://makassar. tribunnews.com/2016/09/26/breakingnews-demo-soal-kerajaan-gowa-kantordprd-dibakar.

Pelras, C. (2006). Manusia Bugis. Jakarta: Nalar \& Forum Jakarta-Paris, EFEO.

Poelinggomang, E. P. L. (2004). Perubahan Politik dan Hubungan Kekuasaan Makassar 19061942. Yogyakarta: Ombak.

Rochayati, S. (2010). Jatuhnya Benteng Ujung Pandang Makassar Pada Belanda (VOC). Bachelor Thesis (Unpublish). Surakarta: Fakultas Keguruan dan Ilmu Pendidikan Universitas Sebelas Maret.

Yasen, S. (2008). Maestro 27 Karaeng BugisMakassar. Makassar: Pustaka Refleksi. 